\title{
Should We Resect all Multiple Intraspinal Extradural Arachnoid Cysts? A Case Report
}

\author{
Tüm Multipl Intraspinal Ekstradural Araknoid Kistlere Rezeksiyon \\ Yapulmalı mı? Bir Olgu Sunumu
}

\author{
Jun YU, Sheng CHEN, Jianmin ZHANG, Qun WU, Jing XU \\ Second Affiliated Hospital, College of Medicine, Zhejiang University, Department of Neurosurgery, Hangzhou, China
}

Correspondence address: Jing XU / E-mail: Jxu8798@gmail.com

\begin{abstract}
Multiple spinal extradural arachnoid cysts (SEACs) are relatively rare lesions, which may cause symptoms due to spinal cord compression. Radical resection of multiple SEACs during one-stage surgery is the primary treatment for the rare lesion, because of its effective and safe operation. Here, we present a 13-year-old female, who presented with a 3-month history of progressive weakness in the right leg. For the first time, we reported partial resection of multiple SEACs without treating the other parts, can also lead to a favorable outcome. No change in the cysts and spinal deformity were observed during a follow-up period of 5 years.
\end{abstract}

KEYWORDS: Extradural arachnoid cyst, Spinal cord compression, Magnetic resonance imaging (MRI)

öz

Multipl spinal ekstradural araknoid kistler (SEAC'ler) nispeten nadir lezyonlardır ve omurilik kompresyonu nedeniyle belirtilere yol açabilirler. Bu nadir lezyonlar için temel tedavi, etkin ve güvenli bir ameliyat olması nedeniyle tek aşamalı cerrahiyle radikal rezeksiyondur. Burada sağ bacakta 3 aydır progresif zayıflık öyküsüyle gelen 13 yaşında bir kız sunulmuştur. İlk defa olarak multipl SEAC'lerde diğer kısımları tedavi etmeden kısmi rezeksiyonun olumlu bir sonuç sağlayabileceğini bildirilmiştir. Beş yıllık bir takip döneminde kistlerde ve spinal deformitede bir değişiklik gözlenmemiştir.

ANAHTAR SÖZCÜKLER: Ekstradural araknoid kist, Spinal kord basısı, Manyetik rezonans görüntüleme (MRG)

\section{INTRODUCTION}

Spinal extradural arachnoid cysts (SEACs) are relatively rare, accounting for $\sim 1 \%$ of primary tumors of the spinal cord (1). However, with the widespread use of MRI, the number of cases diagnosed has increased in recent years (11). Most of the cases have been solitary SEACs, and only a few cases of multiple SEACs have be reported $(10,16,17,18)$. Some authors have stated that radical resection of multiple SEACs is effective and safe, allowing prevention of SEAC recurrence $(5,10,16,17)$. However, we report, for the first time, that partial resection of multiple SEACs without treating the other parts can also lead to a favorable outcome. No change in the cysts was observed during a follow-up period of 5 years.

\section{CASE STUDY}

\section{History-taking and examination}

A 13-year-old female was admitted to the Second Affiliated Hospital of Zhejiang University (Hangzhou, China) presented with a 3-month history of progressive weakness in the right leg that caused an unstable gait. She did not report a feeling of numbness or difficulties in movements in the bowel or bladder.
Upon physical examination, we found no spinal deformity, cutaneous stigmata of neurological disease, or dysmorphic features. Hyperesthesia at the level of T5 and below, together with weakness of the right leg on manual muscle testing which manifested as grade 4 on the Medical Research Council (MRC) scale, was noted. Reflexes were intact and symmetrical with flexor plantar responses.

MRI showed a huge extradural lesion on the dorsal aspect of the spinal cord from the C-7 to the T-8 level. There were three separate SEACs at these levels: (1) from the upper margin of $\mathrm{C} 7$ to the upper margin of T2; (2) from the upper margin of T2 to the upper margin of T3; and (3) from the upper margin of T3 to the upper margin of T8. The lesion produced low and high signal intensities on T1- and T2-weighted MRI, and showed no contrast enhancement. MRI revealed severe compression of the spinal cord, especially at the level of T5 to T8. These findings led to a diagnosis of multiple SEACs (Figure1).

Surgery was carried out from the T4 to T7 vertebrae. The spinal canal was occupied by a large translucent cyst whose wall was probably formed by a thickened arachnoid membrane (Figure 2). The cyst was readily separated from the dura, which had been pushed forward by the cyst and appeared to 


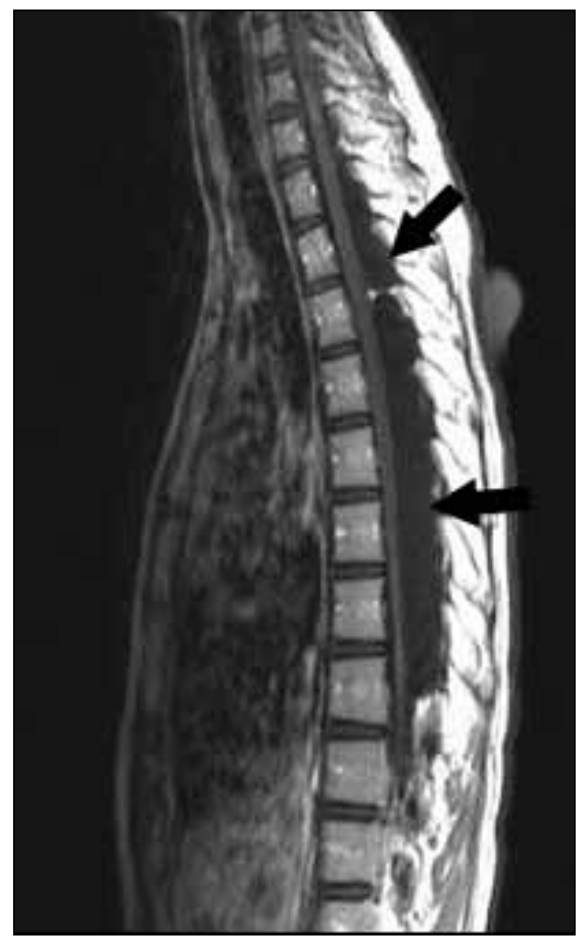

Figure 1: $M R I$ showing a huge extradural lesion on the dorsal aspect of the spinal cord from the C7 to T8 level (arrow). Severe compression of the spinal cord was observed, especially at the level of T5 to T8.

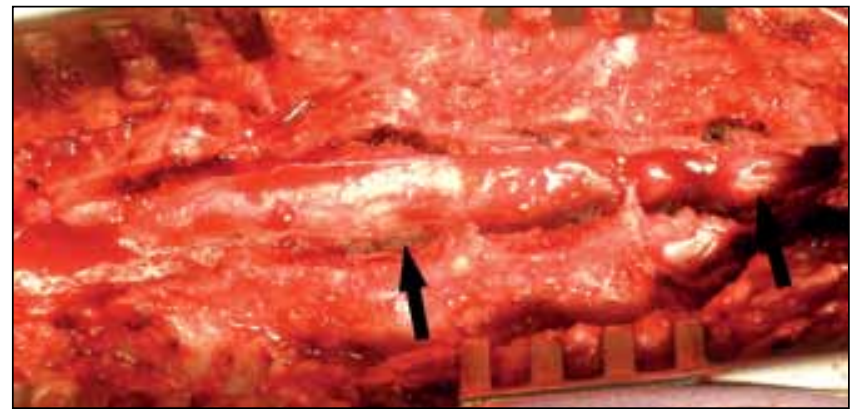

Figure 2: Intraoperative photographs show the cysts (arrow). arise from a small "neck" protruding through a defect in the dura of the right T-7 nerve root. The cyst neck was excised and the defect simultaneously sutured in a watertight fashion. The spinal cord was completely decompressed. The cysts contained no neural tissue and the lining comprised arachnoid cells upon macroscopic examination. Histopathological examination of the cyst wall showed fibrocollagenous layers with a thin layer of simple squamous epithelium (Figure 3).

The patient was discharged home in a stable condition on the eighth postoperative day. The patient demonstrated an astonishingly fast progressive recovery of all neurologic deficits. At 1-year follow-up, the motor function in her right leg returned back to MRC grade 5 and with no sensory deficit. MRI showed that the arachnoid cyst from T3 to T8 was completely removed, whereas the cysts from C7 to T2 and from T2 to T3 did not change at 1 year after surgery (Figure 4). During 5-year follow-up, the two cysts from C7 to T2 and from T2 toT3 did not enlarge. Three-dimensional CT did not demonstrate spinal deformity or stenosis (Figure 5).

\section{DISCUSSION}

Etiology: Extradural cysts are relatively rare. Because their inner wall comprise arachnoid cells upon microscopic examination, they are also called SEACs. The etiology and pathogenesis of pediatric SEACs is incompletely understood, but they may be caused by congenital or acquired factors. These include trauma, iatrogenic damage, meningeal infection or dural defects. Most reported cases have been congenital in origin (9). These SEACs occur at any age, but have a peak incidence at 11-20 years. They are usually in the middle or lower thoracic region, rarely in the lumbosacral region $(3,4)$. SEACs are usually considered to show "outpouching" of the arachnoid through a small dural defect to form an arachnoid hernia or arachnoid diverticula. These defects may be congenital or acquired. Idiopathic SEACs result from congenital defects or an arachnoid diverticulum; nevertheless, acquired SEACs can be the result of trauma to the spinal cord or after lamnectomy $(2,13)$.

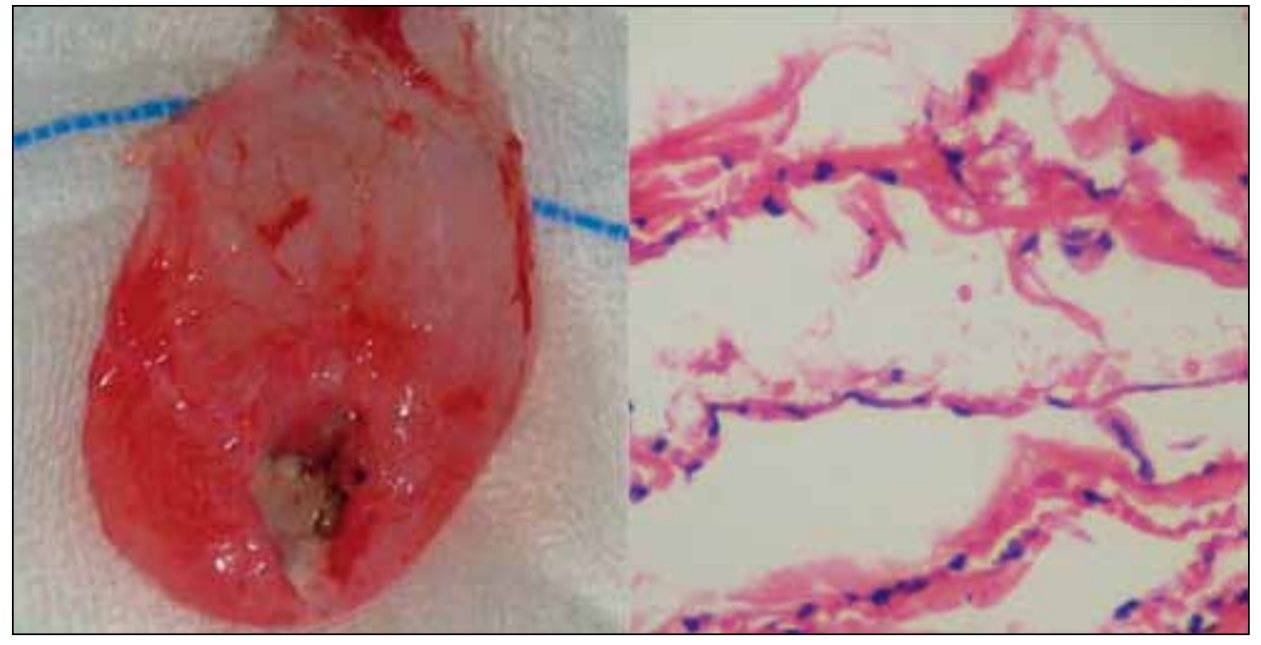

Figure 3: Macroscopic image of the cyst and its stalk (left). Histopathological examination of the cyst wall showed fibrocollagenous layers with a thin layer of simple squamous epithelium (right). 
Clinical presentation: Motor deficit is more serious than superficial sensory dysfunction in patients with multiple SEACs. The symptoms of patients with thoracic SEACs develop

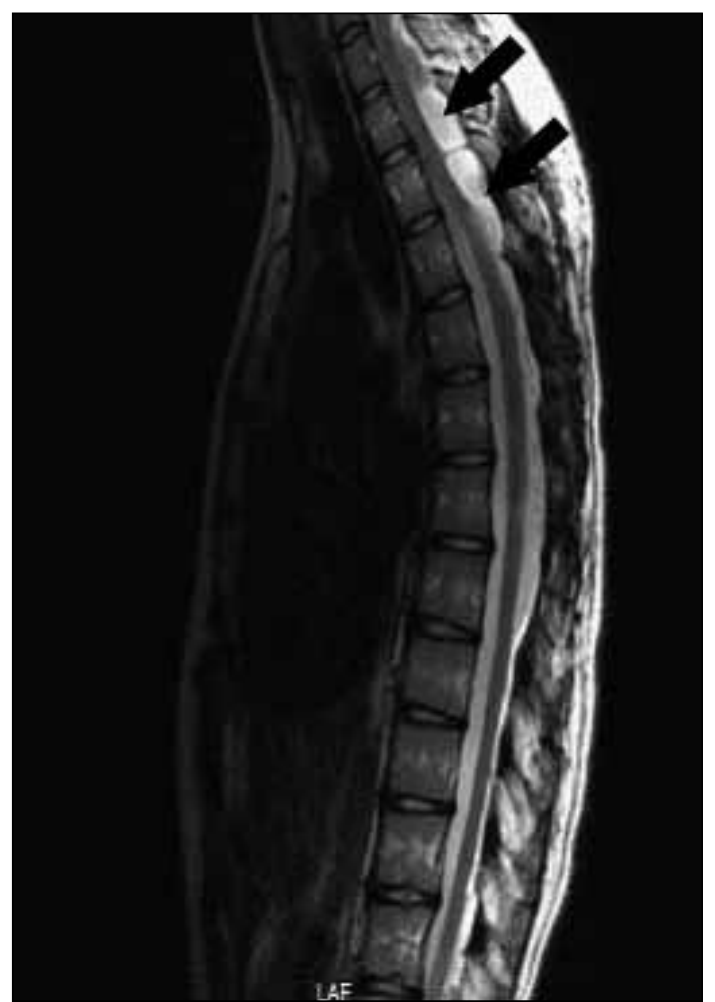

Figure 4: MRI showing that compression of the spinal cord was relieved and the remaining two cysts did not enlarge 1-year after surgery (arrow).

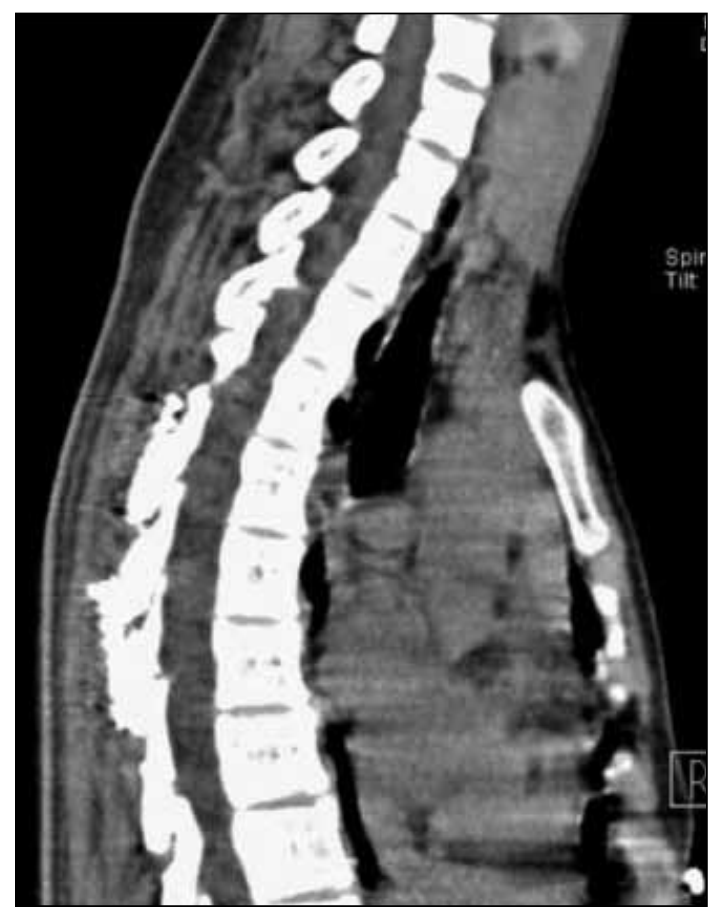

Figure 5: Three-dimensional CT showing no spinal-canal stenosis 5 years after surgery. gradually accompanied by intermittent paresis of both legs. This symptom can be spontaneously relieved. The presentation of root pain is rare in lesions in the middle to lower thoracic area, but is more obvious in lumbar lesions. Progressive weakness of limbs is usually the manifestations of SEACs in the lumbar dorsal region. However, in some patients, root pain is due to the rachiokyphosis and scoliosis deformity, not due to the cysts. There are other manifestations in SEACs patients: muscle atrophy, limb paralysis, gait disorder, and dysfunction of the bowel and bladder $(7,19,20)$.

Diagnosis: Under MRI, spindle-shaped or curved SEACs are usually located in the posterior parts of the spinal cord. Lesions appear hyperintense on T2-weighted images but hypointense on T1-weighted images, similar to the features seen for cerebrospinal fluid (CSF). The cyst wall cannot be displayed on MRI. Some lesions even invade the intervertebral foramen. Axial MRI clearly shows the shift of the compressed spinal cord. Radiography can show compression of the related pedicle bones, enlargement of the spinal canal, and increase in the anteroposterior and pedicle distance. Enhanced CT and myelography also have diagnostic value in SEACs, but MRI is the best choice $(16,17,21)$.

Surgical management: Multiple SEACs should be diagnosed and treated as soon as possible to prevent progressive neurologic dysfunction. Some neurosurgeons state that the small cysts can be treated conservatively, particularly in asymptomatic patients. However, long-term follow-up is needed. Ertan et al. described a 14-year-old subject with an extradural thoracolumbar arachnoid cyst who was followed up for 2 years without surgical intervention who did not have additional neurological impairment (6). Rimmelin also reported one clinical study involving conservative treatment of extradural spinal arachnoid cysts because of mild symptoms (14). The cysts have a small valve-like defect which connects them to the subarachnoid space. Surgical treatment is indicated in patients with significant signs such as cyst enlargement, bone compression, and neurological impairment $(5,15,17)$. Successful treatment of SEACs requires total excision whenever possible. Complete resection of the pedicle is essential to prevent cyst recurrence. For cysts adhering to the spine or nerve root, complete resection is difficult, so fenestration, partial resection, or bypass of the cyst is preferred. Multiple extradural arachnoid cysts are very rarely reported in children. Cyst excision at the level of the spinal cord leads to a favorable outcome. Samura et al. removed a solitary largest cyst in which spinal-cord compression appeared to be most severe in multiple SEACs. Unfortunately, after 2 weeks, the extradural dead space became larger and spinal-cord compression became much more severe. Further surgery was undertaken to remove all the multiple cysts in the extradural space. After removal of all the cysts and repair of the dural fistulas, the dura was lifted up to the lamina using tenting sutures to minimize the extradural dead space. The patient recovered gradually over 3 months, and MRI after 1 year showed complete relief of spinal-cord compression (16). Takagaki reported an 11-year-old male diagnosed with 
multiple SEACs extending from the T5 to L5 vertebrae. Surgery was undertaken on cysts only in the vertebra thoracalis, but cysts in the lumbar region were untreated. Two years after surgery, no recurrence was observed and preoperative symptoms improved. Multiple SEACs often occupy some segments, so removal of the whole cyst requires resection of some segments of the vertebra and spinous process, but spinal kyphosis or scoliosis often occur after surgery. Even after laminoplasty, the probability of recurrence of these deformities is high, which have obvious effects on the growth and development of children $(8,12)$. It is possible that some cysts would not increase in size throughout the patient's life. With a combination of preoperative imaging and monitoring of symptoms, we can accurately determine which arachnoid cyst induces the symptoms. Partial removal of the cyst that causes the symptoms reduces the possible interference in spinal stability. In our case, spinal-cord compression was most serious at T5 to T8, together with hypesthesia at the level of T5 and below. We believed that the cyst extending from T3 to T8 was the "responsible cyst" that caused the symptoms. Excision of the responsible cyst can immediately relieve symptoms. The suspension of the dura during surgery is very important to reduce the epidural cavity and prevent CSF pressure filling to form a new compressive cyst on the spinal cord. Laminoplasty was carried out on only four segments, so postoperative spinal stability was not greatly affected. Furthermore, after 5 years of follow-up, spinal deformity or spinal-canal stenosis was not observed. If we had excised all three cysts, laminoplasty should have been undertaken from C7 to T7, and could have resulted in death. The patient had uneventful postoperative growth with improvement in neurological symptoms, but the residual cysts require close follow-up.

In conclusion, on the premise of accurately determining the responsible cyst, we advocate excising part of multiple SEACs to improve symptoms. The more radical the removal, the less chance of recurrence, however, this comes with a greater chance of disrupting spinal stability.

\section{REFERENCES}

1. Chae KH, Kim SW, Shin H: Septated extradural arachnoid cyst in thoracolumbar spine causing myelopathy. J Korean Neurosurg Soc 40:381-383, 2006

2. Chang IC, Chou MC, Bell WR, Lin ZI: Spinal cord compression caused by extradural arachnoid cysts. Clinical examples and review. Pediatr Neurosurg 40:70-74, 2004

3. Congia S, Coraddu M, Tronci S, Nurchi G, Fiaschi A: Myelographic and MRI appearances of a thoracic spinal extradural arachnoid cyst of the spine with extra-and intraspinal extension. Neuroradiology 34: 444-446, 1992

4. Dastur HM:The radiological appearances of spinal extra-dural arachnoid cysts. J Neurol Neurosurg Psychiatry 26: 231-235, 1963

5. de Oliveira RS, Amato MC, Santos MV, Simão GN, Machado HR: Extradural arachnoid cysts in children. Childs Nerv Syst 23:1233-1238, 2007
6. Ergun E, Borcek AO, Cemil B, Dogulu F, Baykaner MK: Should we operate all extradural spinal arachnoid cysts? Report of a case. Turkish Neurosurgery 18:52-55, 2008

7. Fiss I, Danne M, Hartmann C, Brock M, Stendel R: Rapidly progressive paraplegia due to an extradural lumbar meningocele mimicking a cyst. J Neurosurg Spine 7:75-79, 2007

8. Hida S, Naito M, Arimizu J, Morishita Y, Nakamura A: The transverse placement laminoplasty using titanium miniplates for the reconstruction of the laminae in thoracic and lumbar lesion. Eur Spine J 15: 1292-1297, 2006

9. Isu $T$, lizuka $T$, Iwasaki $Y$, Nagashima $M$, Akino $M$, Abe $H$ : Spinal cord hemiation associated with an intradural spinal arachnoid cyst diagnosed by magnetic resonance imaging. Neurosurgery 29:137-139, 1991

10. Kanaan IN, Sakati N, Otaibi F: Type I congenital multiple intraspinal extradural cysts associated with distichiasis and lymphedema syndrome. Surg Neurol 65:162-166, 2006

11. Liu JK, Cole CD, Sherr GT, Kestle JR, Walker ML: Noncommunicating spinal extradural arachnoid cyst causing spinal cord compression in a child. J Neurosurg 103: 266-269, 2005

12. Myles LM, Gupta N, Armstrong D, Rutka JT: Multiple extradural arachnoid cysts as a cause of spinal cord compression in a child. Case report. J Neurosurg 91 (1 Suppl):116-120, 1999

13. Rabb CH, McComb JG, Raffel C, Kennedy JG: Spinal arachnoid cysts in the pediatric age group: An association with neural tube defects. J Neurosurg 77:369-372, 1992

14. Rimmelin A, Clouet PL, Salatino S, Kehrli P, Maitrot D, Stephan M, Dietemann JL: Imaging of thoracic and lumbar spinal extradural arachnoid cysts: Report of two cases. Neuroradiology 39:203-206, 1997

15. Rohrer DC, Burchiel KJ, Gruber DP: Intraspinal extradural meningeal cyst demonstrating ball-valve mechanism of formation. J Neurosurg 78:122-125, 1993

16. Samura K, Morioka T, Miyagi Y, Nagata S, Mizoguchi M, Mihara F, Sasaki T: Surgical strategy for multiple huge spinal extradural meningeal cysts. J Neurosurg (4 Suppl) 107: 297-302, 2007

17. Suryaningtyas W, Arifin M: Multiple spinal extradural arachnoid cysts occurring in a child. J Neurosurg (2 Suppl) 106:158-161, 2007

18. Takagaki T, Nomura T, Toh E, Watanabe M, Mochida J: Multiple extradural arachnoid cysts at the spinal cord and cauda equina levels in the young. Spinal Cord 44: 59-62, 2006

19. Tureyen K, Senol N, Sahin B, Karahan N: Spinal extradural arachnoid cyst. Spine J 9(8): e10-15, 2009

20. Wang MY, Levi AD, Green BA: Intradural spinal arachnoid cysts in adults. Surg Neurol 60:49-55, 2003

21. Yabuki S, Kikuchi S, Ikegawa S: Spinal extradural arachnoid cysts associated with distichiasis and lymphedema. Am J Med Genet A 143A(8): 884-887, 2007 